Correspondence: M. Don, Paediatric Dept, Allergology and Pulmonology Unit, School of Medicine DPMSC, University of Udine, P.le S. Maria della Misericordia, 33100 Udine, Italy. E-mail: max.don@libero.it

Statement of Interest: None declared.

\section{REFERENCES}

1 Lorgelly PK, Atkinson M, Lakhanpaul M, et al. Oral versus i.v. antibiotics for community-acquired pneumonia in children: a costminimisation analysis. Eur Respir J 2010; 35: 858-864.

2 Atkinson M, Lakhanpaul M, Smyth A, et al. Comparison of oral amoxicillin and intravenous benzyl penicillin for community acquired pneumonia in children (PIVOT trial): a multicentre pragmatic randomised controlled equivalence trial. Thorax 2007; 62: 1102-1106.

3 Don M, Fasoli L, Paldanius M, et al. Aetiology of communityacquired pneumonia: serological results of a paediatric survey. Scand J Infect Dis 2005; 37: 806-812.

4 Don $\mathrm{M}$, Valent F, Korppi M, et al. Efficacy of serum procalcitonin in evaluating severity of community-acquired pneumonia in childhood. Scand J Infect Dis 2007; 39: 129-137.

5 Korppi M, Don M, Valent F, et al. The value of clinical features in differentiating between viral, pneumococcal and atypical bacterial pneumonia in children. Acta Paediatr 2008; 97: 943-947.

DOI: $10.1183 / 09031936.00170809$

\title{
Endocrinological derangement in COPD
}

\section{To the Editors:}

With the greatest interest I have read the comprehensive review "endocrinological derangements" in chronic obstructive pulmonary disease (COPD) by LAGHI et al. [1]. Arriving at the last page, where the authors discussed the reninangiotensin-aldosterone system, I have read: "the presence of sympathetic neuropathy..." and "...the possibility that autonomic neuropathy is caused by intraneural hypoxaemia".

In COPD and other diseases such as heart failure and obstructive sleep apnoea the concept of autonomic nervous system dysbalance with increased sympathetic activation and reduced parasympathic activity has been recognised [2-6]. Recent work published in this journal on normoxic COPD patients demonstrated that slow breathing reduces sympathoexcitation and improves baroreflex sensitivity, raising possible therapeutic implications concerning the autonomic nervous system [7]. There is a strong mutual interaction between angiotensin and the sympathetic nervous system [8]. This interaction may partly account for the activation of the renin-angiotensin-aldosterone system LAGHI et al. [1] competently described in COPD patients.

Interestingly, work published in the same volume as the review on endocrinological derangements in COPD demonstrated marked alterations in cardiac autonomic control in patients with pulmonary artery hypertension [4]. The authors and an adjoining editorial discussed various causes of the observed findings, such as sympathetic overactivity related to an overactive chemoreflex and baroreflex, increased filling pressure and blood gas alterations $[4,6]$.

Thus, there is growing evidence demonstrating a dysfunction of the autonomic nervous system in COPD patients [2]. This evidence stems from evaluating the baroreflex sensitivity, heart rate variability and muscle sympathetic nerve activity, and is corroborated by research on other diseases such as heart failure, sleep apnoea and pulmonary hypertension $[3,6]$. This evidence can not be readily explained by intraneuronal hypoxaemia. However, in very severe COPD patients and long-standing severe hypoxaemia without supplemental oxygen alterations of the peripheral nervous system may ensue.

\section{S. Andreas}

Ärztlicher Leiter, Lungenfachklinik Immenhausen/Kr. Kassel, Pneumologische Lehrklinik Universität Göttingen, Immenhausen, Germany.

Correspondence: S. Andreas, Ärztlicher Leiter, Lungenfachklinik Immenhausen/Kr. Kassel, Pneumologische Lehrklinik Universität Göttingen, Robert-Koch-Str. 3, 34376 Immenhausen, Germany. E-mail: sandreas@lungenfachklinik-immenhausen.de

Statement of Interest: None declared.

\section{REFERENCES}

1 Laghi F, Adiguzel N, Tobin MJ. Endocrinological derangements in COPD. Eur Respir J 2009; 34: 975-996.

2 Andreas S, Anker SD, Scanlon PD, et al. Neurohumoral activation as a link to systemic manifestation of chronic lung disease. Chest 2005 128: 3618-3624.

3 Floras JS. Clinical aspects of sympathetic activation and parasympathetic withdrawal in heart failure. J Am Coll Cardiol 1993; 22: Suppl. A, 72a-84a.

4 Wensel R, Jilek C, Dorr M, et al. Impaired cardiac autonomic control relates to disease severity in pulmonary hypertension. Eur Respir $J$ 2009; 34: 895-901.

5 Andreas S, Eichele G. Sleep apnoea: time to consider clock genes. Eur Respir J 2008; 32: 1-2.

6 Naeije R, van de Borne P. Clinical relevance of autonomic nervous system disturbances in pulmonary arterial hypertension. Eur Respir $J$ 2009; 34: 792-794.

7 Raupach T, Bahr F, Herrmann P, et al. Slow breathing reduces sympathoexcitation in COPD. Eur Respir J 2008; 32: 387-392.

8 Reid IA. Interactions between ANG II, sympathetic nervous system, and baroreceptor reflexes in regulation of blood pressure. Am J Physiol 1992; 262: E763-E778. 